\author{
Aleksandra Czajkowska \\ University of Science and Technology in Bydgoszcz, Faculty of Mechanical Engineering \\ Al. prof. S. Kaliskiego 7, 85-796 Bydgoszcz, e-mail: czajkowska.aleksandra91@gmail.com
}

\title{
THE CHANGES IN THE POLISH ENERGY SECTOR TO REDUCE THE POLLUTANT EMISSIONS IN THE ENVIRONMENT
}

\begin{abstract}
The Polish Energy Sector is one of the most difficult lines of business because among other things, of the existing legal provisions, and standards relating to pollutant emissions. In the coming years, in the Polish Energy Sector breakthrough changes related to develop the energy facilities and with respect to the environmental protection will have to be introduced. During the generation of electricity harmful residues are produced, which are counteracted by equipment designed for flue gas cleaning. The Energy Sector should be concentrating on searching for the implementation of innovations to achieve emission standards.
\end{abstract}

\section{Key words}

environmental protection, EU directives, Decree from the Polish Environment Minister, Duo-block, the reduction of ash particles, $\mathrm{SO}_{\mathrm{x}}$ and $\mathrm{NO}_{\mathrm{x}}$ emissions

\section{Introduction}

European Union Member States must adapt to the changing policy and rules. For many years, activities have been adopted in order to support EU members in the protection of the natural environment, climate and the reduction of greenhouse gas emissions. The activities undertaken enable effective promotion of the use of renewable energy sources in order to obtain electricity [1].

The continuous increase in demand and supply for electricity, in relation to the decreasing access to natural resources, causes a conflict between maintaining energy security and the availability of the sources necessary to generate electricity. The emission restrictions, which are imposed by the European Union on the Polish Energy Sector, promote the generation of electricity from Renewable Energy Sources (e.g. 3×20 climate package) [2].

The natural resource depletion and fast growing technology in cities or industrial plants development will require the satisfying of a higher and higher energy demand. This situation can lead to a situation where the traditional models of energy production in Poland will slowly become insufficient or technologically obsolete as well as the environmental protection. The energy sector should also concentrate on searching for and implementing innovations, to ensure emission standards [3].

\section{EU requirements and Poland's regulations}

The European Commission has developed an energy policy for countries belonging to the European Union, which requires the fulfillment of the aims included in the Green Book [4]. The goals concern the reduction of greenhouse gas emissions by at least $20 \%$ by the year 2020 compared to data from 1990 . In addition, the proportion of energy obtained from renewable sources must also increase to $20 \%$ by 2020 . Furthermore, the new energy policy will be developed by the European Commission and contains:

- an increase in energy efficiency,

- improving energy security,

- $\quad$ extending the area of renewable energy use for biofuels,

- the development of competitive sectors on the energy market (reference to the area of fuels and electricity),

- minimizing the impact of the energy sector on the natural environment.

Topics related to the increase of energy efficiency have been treated in a special way by the European Commission. Completion of this point by EU Member States, will allow achievement of the remaining objectives of the new energy policy, which is being carried out. 
The destructive impact of industrial development on the environmental and climatic changes, offers the opportunity to look at specific assumptions adopted by the European Union in order to counteract these harmful factors. The burning of raw materials and fossil fuels causes the emission of many harmful chemical compounds, which have a negative impact on the natural environment.

A directive of the European Parliament and of the Council 2010/75/EU from 24th November 2010 on the issue of industrial pollution caused the introduction of key changes in Polish law, which concern the environmental protection regulations [5]. The most important changes relate to the introduction of exacerbations in the regulations relating to the emission standards of pollutions by industrial concerns. Primarily, the Industrial Emissions Directive (IED) indicates the reduction of sulfur dioxide, nitrogen oxides and dust produced by energy combustion.

There are also two regulations in the Regulations of the Environment Minister in Poland, which relate to environmental protection and also limiting the emission of dust-gas pollution:

- The Regulation of the Environment Minister of 30th October 2014, concerning the requirements for the measurement of emission volumes and the water amount [6].

- The Regulation of the Environment Minister of 4th November 2014, 4 on the emission standards for certain types of installations, combustion plants and equipment incineration or coincineration of waste [7].

The Regulations in Poland have been specified for limiting the values for emissions of such chemical compounds as $\mathrm{NO}_{x}, \mathrm{SO}_{\mathrm{x}}$ and dust to the environment, depending on the power of the boiler. In the Regulations of the Environment Minister, there are schedules relating to emission standards for devices with a nominal heat output of not less than $50 \mathrm{MW}$. The table below contains a list of selected documents that relate to the requirements affecting the Polish energy sector (Table 1.).

Table 1. A brief summary of documents affecting the Polish energy sector

\begin{tabular}{|c|c|c|}
\hline Type of document & Working area & Objectives included in the document \\
\hline Green Book & $\begin{array}{l}\text { Sustainable, competitive } \\
\text { and safe energy }\end{array}$ & $\begin{array}{l}\text { - increase of energy efficiency } \\
\text { - } \quad \text { improvement of energy security } \\
\text { - Sources) use area for biofuels } \\
\text { - development of competitive sectors on the } \\
\text { energy market (reference to the area of } \\
\text { fuels and electricity) } \\
\text { - minimization of the impact of the energy } \\
\text { sector on the natural environment }\end{array}$ \\
\hline New energy policy & $\begin{array}{l}\text { Energy sector, } \\
\text { renewable energy and } \\
\text { environmental } \\
\text { protection }\end{array}$ & $\begin{array}{l}\text { - increase in the use of renewable energy } \\
\text { - } \quad \text { increased importance of biofuels on the } \\
\text { transport fuels market } \\
\text { - } \quad \text { protection of trees against excessive use for } \\
\text { the production of biomass } \\
\text { - rational use of agricultural areas for the } \\
\text { creation of RES areas (Renewable Energy } \\
\text { Sources) }\end{array}$ \\
\hline $3 \times 20 \%$ package & $\begin{array}{l}\text { Power engineering, } \\
\text { including RES } \\
\text { (Renewable Energy } \\
\text { Sources) and reduction } \\
\text { of greenhouse gases }\end{array}$ & $\begin{array}{l}\text { - } \quad \text { reduction of greenhouse gas emissions at } \\
\text { - } 20 \% \\
\text { - } \quad \text { use of renewable energy sources in relation } \\
\text { to the total electricity production by } 20 \%\end{array}$ \\
\hline $\begin{array}{l}\text { Directive of the European } \\
\text { Parliament and of the } \\
\text { Council 2010/75 / EU of } \\
\text { November 24, } 2010\end{array}$ & $\begin{array}{l}\text { Emissions of industrial } \\
\text { pollution and regulations } \\
\text { on environmental } \\
\text { protection }\end{array}$ & $\begin{array}{l}\text { - } \text { reduction of sulfur dioxide, nitrogen oxides } \\
\text { and dusts originating from energy } \\
\text { combustion } \\
\text { implementation of the so-called flexible } \\
\text { derogation mechanism }\end{array}$ \\
\hline
\end{tabular}




\begin{tabular}{|c|c|c|}
\hline Type of document & Working area & Objectives included in the document \\
\hline Transitional National Plan & $\begin{array}{l}\text { Industrial facilities } \\
\text { and reduction of } \\
\text { emissions from industry }\end{array}$ & $\begin{array}{l}\text { - introduction of sulfur dioxide, nitrogen } \\
\text { oxide or flue gas emission standards } \\
\text { - reduction of emitted harmful chemical } \\
\text { compounds by industrial facilities }\end{array}$ \\
\hline $\begin{array}{l}\text { Regulation (EC) No } \\
166 / 2006 \text { of the European } \\
\text { Parliament and of the } \\
\text { Council of } 18 \text { January } 2006\end{array}$ & $\begin{array}{l}\text { Pollutant Release and } \\
\text { Transfer Register (PRTR) }\end{array}$ & $\begin{array}{l}\text { - a register is a tool to enable the public to } \\
\text { access environmental information about } \\
\text { the transfer of pollutants into the air, } \\
\text { water, soil, form different industrial plants }\end{array}$ \\
\hline $\begin{array}{l}\text { Regulation of the Minister } \\
\text { of the Environment of } \\
\text { August 14, 2009 (Journal of } \\
\text { Laws No. 141, item 1154) }\end{array}$ & $\begin{array}{l}\text { Reports on the creation } \\
\text { of the National Pollutant } \\
\text { Release and Transfer } \\
\text { Register }\end{array}$ & $\begin{array}{l}\text { introduction of a report template on the } \\
\text { amount and type of pollution released by } \\
\text { the plant during the year }\end{array}$ \\
\hline
\end{tabular}

Source: Author's

Fulfillment the EU's requirements by the Polish energy industry, which relate to reducing emissions of pollutants, will be a long and extremely expensive process. Expenditure incurred to build a modern, highefficiency block with a high power significantly exceeds the expenditure on the revitalization of an energy facility with the same parameters. Investors decide to choose the second option, firstly for economic reasons, secondly with a view to introducing stricter EU standards in the future (for example, price increases for the emission of carbon dioxide into the atmosphere).

Performing the revitalization of facilities, in the energy sector means modernizing the existing power units, for example, improving turbine and boiler modules, or expanding it with installation to capture sulfur dioxide, nitrogen dioxide, and with the reduction of dust pollination to the environment. The implementation of the above-mentioned measures enables extending the working time of modernized power units, of course after confirming that the relevant emission standards have been met. Performing revitalization allows for extending the operation of power facilities even up to 2030, in the implementation of certain conditions imposed by the European Union. Activities modernizing energy facilities make it possible for the energy sector to meet the requirements of EU directives and obtaining a high level of efficiency of individual elements of the power unit.

\section{Conventional installations of exhaust gas cleaning systems}

The side effect of energy production by a power station is the generation of toxic pollutions in the environment.

In the dust removal during the flue gas cleaning process there can be found such chemical compounds as: oxides $\left(\mathrm{O}_{2}\right)$, in particular carbon monoxide $(\mathrm{CO})$, sulfur dioxide $\left(\mathrm{SO}_{2}\right)$, carbon dioxide $\left(\mathrm{CO}_{2}\right)$, nitrogen dioxide $\left(\mathrm{NO}_{2}\right)$, hydrogen fluoride (HF) and carbon tetrachloride $\left(\mathrm{CCl}_{4}\right)$ [8]. In power units, apart from the installation of the fuel combustion process, are devices for converting the thermal energy generated by an energy boiler, to electricity. These are the following objects [9]:

- turbines;

- turbogenerators;

- cooling system with a condenser (condenser);

- auxiliary devices producing heat energy during boilers' working periods (in the case of using steam turbines).

The above list of devices converting thermal energy into electricity is very general. Each installation included in the power units mainly depends on the character of the production and the fuel used. Most of the chemical compounds listed at the beginning are highly toxic for people and for the environment. In order to capture dust and gas particles in the power unit, installations for flue gas desulphurization, denitrification and removal of dust are used (PM 10 and PM 2.5) [10].

\section{Flue gas desulfurization methods}

There are three methods for flue gas desulphurization. The wet method consists in humidifying the exhaust gases in the chamber by water, which contains a factor that allows the absorption of sulfur dioxide into the liquid. During the desulphurization process, the exhaust gases are cooled to a temperature per $50-60^{\circ} \mathrm{C}$. 
This method consists in washing the flue with an aqueous lime suspension or limestone in the absorption tower, resulting in calcium sulfite $\left(\mathrm{CaSO}_{3}\right)$. Additional oxygenation of $\mathrm{CaSO}_{3}$ causes its conversion to $\mathrm{CaSO}_{4}$, which after precipitation from the solution is treated (washing and dehydration) resulting in gypsum $\left(\mathrm{CaSO}_{4} \mathrm{X}\right.$ $2 \mathrm{H}_{2} \mathrm{O}$ ). The limestone powder or quicklime powder it is pre-prepared in the form of an aqueous suspension in the right installation. It is then pumped to the absorber by means of pumps. A special circulation pump system, pipelines and nozzle system ensures intensive washing exhaust inside the absorption column. The effectiveness of the process depends to a large extent on the intensity of flue gas washing. This method is one of the first and oldest ways to eliminate sulfur compounds from fumes [11]. Wet desulfurization installations are presented in the diagram below (Fig. 1).

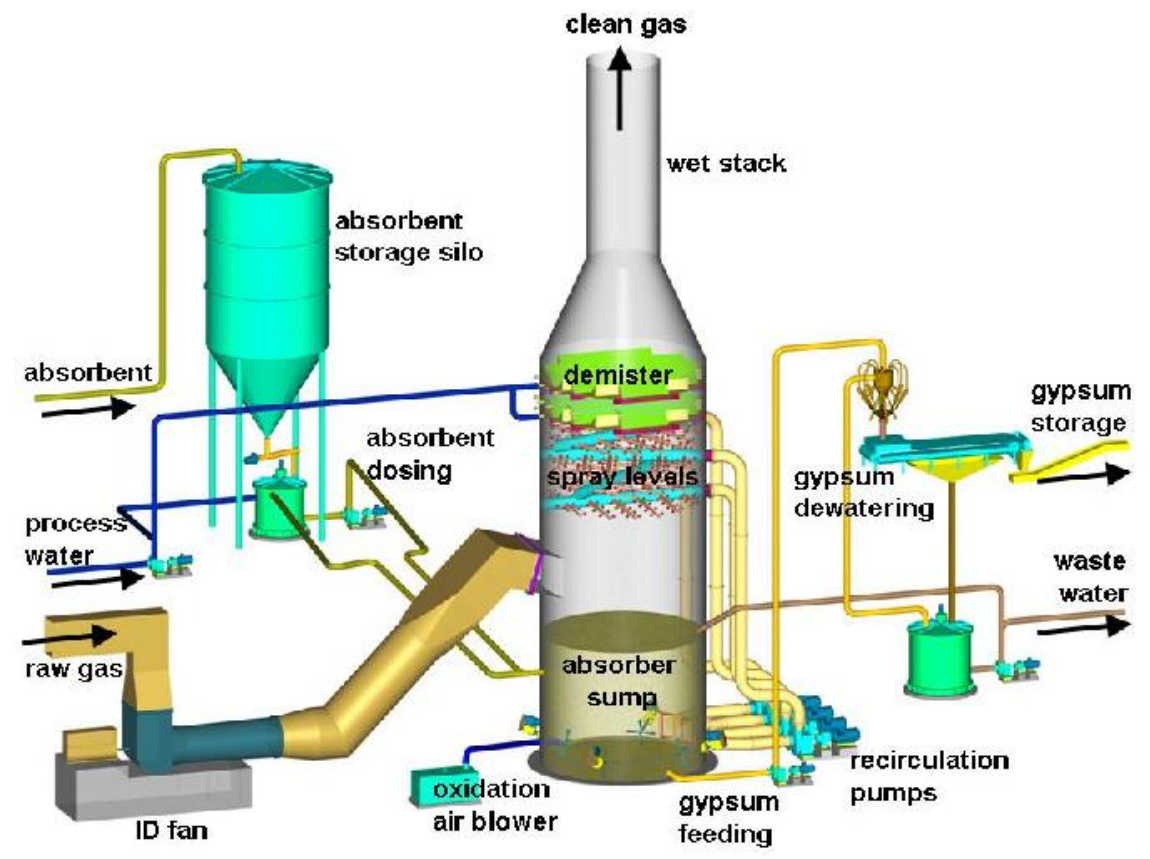

Fig. 1. Wet flue gas desulfurization Source: [12]

Wet flue gas desulfurization has two main disadvantages. The intensive wetting of polluted air causes subsequent costs, which will result from the need to use appropriate equipment to remove water. The second disadvantage is the reheating of the exhaust gases, then may be purification from remaining harmful compounds in the electrostatic precipitator.

The factors associated with the increase in costs caused the management to think about replacing the wet method with other methods of flue gas desulfurization. The wet method was invented and developed as the first method of purification of sulphide exhaust. It is currently and gradually being replaced by the other two techniques for economic and hardware reasons.

In short, the dry method of exhaust after-treatment involves feeding a sorbent into the combustion chamber a substance that absorbs harmful sulfur dioxide, thanks to the use of a suitable installation (Fig. 2). This method involves dosing dry sorbents such as:

- limestone with a $\mathrm{CaCO}_{3}$ content above 90\%;

- hydrated lime: $\mathrm{Ca}(\mathrm{OH})_{2}$;

- burnt lime: $\mathrm{CaO}$;

- dolomit $\mathrm{CaCO}_{3}+\mathrm{MgCO}_{3}$.

The sorbent can be dosed into the boiler in three ways:

- directly mixed with coal (e.g. in a mill);

- blown into the combustion chamber around the flame;

- blown into the combustion chamber above the flame (preferred method).

The dry desulphurisation method (also called the direct method) is based on absorption of sulfur by burnt lime $(\mathrm{CaO})$ obtained from ground limestone, hydrated lime or dolomite. After being introduced into the furnace 
chamber, the sorbent decomposes, i.e. decarbonisation or dehydration according to the reactions, where dQ is the heat of reaction [13]:

$$
\begin{aligned}
\mathrm{CaCO}_{3}+\mathrm{dQ} & =>\mathrm{CaO}+\mathrm{CO}_{2} \\
\mathrm{Ca}(\mathrm{OH})_{2}+\mathrm{dQ} & =>\mathrm{CaO}+\mathrm{H}_{2} \mathrm{O}
\end{aligned}
$$

and then the lime reacts with $\mathrm{SO}_{2}$ according to the reaction [13]:

$$
\begin{gathered}
\mathrm{CaO}+\mathrm{SO}_{2}=>\mathrm{CaSO}_{3}+\mathrm{dQ} \\
\mathrm{CaO}+\mathrm{SO}_{2}+1 / 2 \mathrm{O}_{2}=>\mathrm{CaSO}_{4}+\mathrm{dQ}
\end{gathered}
$$

Dehydration occurs at temperatures above $400^{\circ} \mathrm{C}$, and decarbonation above $750^{\circ} \mathrm{C}$. Previous experience shows that the introduction of limestone powder to the furnace chamber should be carried out in the temperature areas of $780-1200{ }^{\circ} \mathrm{C}$ [13]. Summarizing, calcium oxides and limestone are most often used as sorbents. The process takes place after blowing the sulphurising substance into the combustion zone. The desulfurization step occurs only at the specified optimal temperature prevailing inside the chamber of the combustion process.

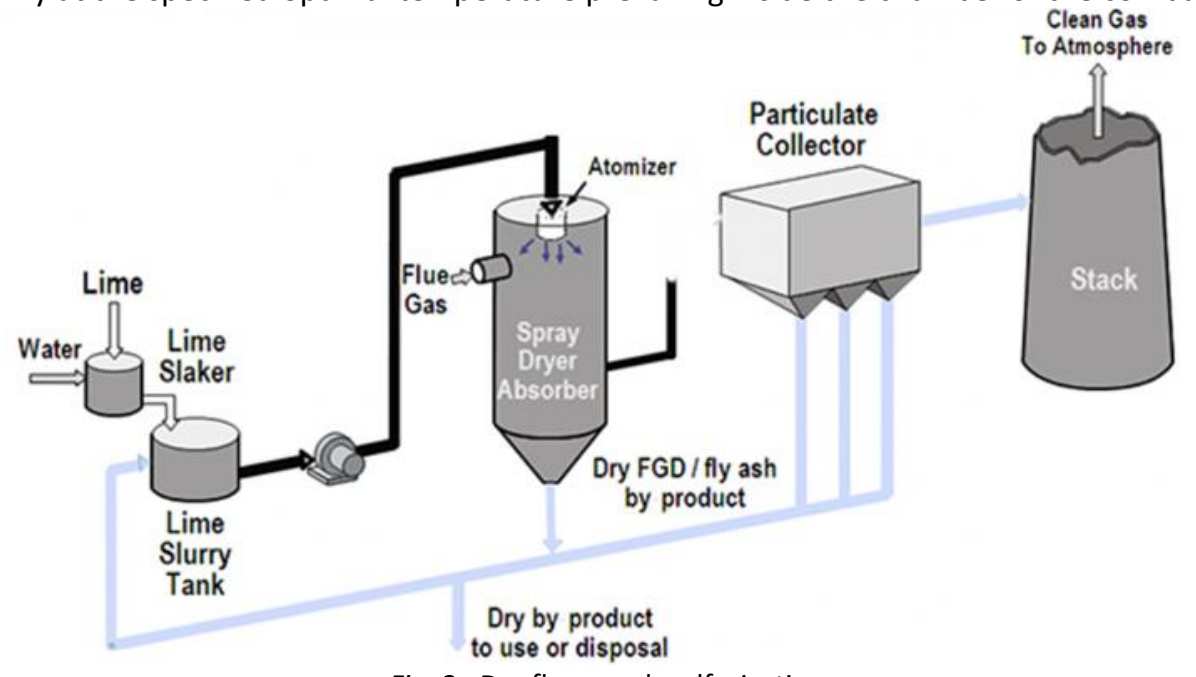

Fig. 2. Dry flue gas desulfurization

Source: [14]

The dry method compared to the other two exhaust purification methods is characterized by a lower desulfurization efficiency. Because of the low implementation costs and the simplicity of construction devices. it is the most often used. The dry method is gradually being replaced by the semi-dry desulfurization technique, due to the lowest efficiency of the purification process in the power industry.

In the introduction, semi-dry desulfurization consists of a stream of very hot flue gas vapor, which contains a sorbent suspension. First step of semi-dry desulfurization process, it consists in dosing the sorbent to the furnace chamber. The following chemical reactions take place [13]:

$$
\begin{gathered}
\mathrm{CaCO}_{3}+\mathrm{dQ}=>\mathrm{CaO}+\mathrm{CO}_{2} \\
\mathrm{Ca}(\mathrm{OH})_{2}+\mathrm{dQ}=>\mathrm{CaO}+\mathrm{H}_{2} \mathrm{O} \\
\mathrm{CaO}+\mathrm{SO}_{2}=>\mathrm{CaSO}_{3}+\mathrm{dQ} \\
\mathrm{CaO}+\mathrm{SO}_{2}+1 / 2 \mathrm{O}_{2}=>\mathrm{CaSO}_{4}+\mathrm{dQ}
\end{gathered}
$$

In the first stage, the process of sulphur dioxide binding proceeds according to mechanisms similar to the dry flue gas desulfurization method, i.e. ground sorbent (limestone with content $\mathrm{CaCO}_{3}$ over $90 \%$, hydrated lime $\mathrm{Ca}(\mathrm{OH})_{2}$, burnt lime $\left.\mathrm{CaO}\right)$ it is dosed to the optimum temperature zone for calcination and binding with sulphur dioxide

into the combustion chamber. The second stage of flue gas desulphurisation is carried out in the exhaust gas sprinkler (absorption washer), which is placed between the exhaust outlet from the boiler and the inlet to the dust collector [13].

$$
\begin{gathered}
\mathrm{CaO}+\mathrm{H}_{2} \mathrm{O}=>\mathrm{Ca}(\mathrm{OH})_{2}+\mathrm{dQ} \\
\mathrm{CaO}+\mathrm{SO}_{2}=>\mathrm{CaSO}_{3}+\mathrm{dQ}
\end{gathered}
$$




$$
\begin{gathered}
\mathrm{Ca}(\mathrm{OH})_{2}+\mathrm{SO}_{2}=>\mathrm{CaSO}_{3}+\mathrm{H}_{2} \mathrm{O}+\mathrm{dQ} \\
\mathrm{Ca}(\mathrm{OH})_{2}+\mathrm{SO}_{2}+\mathrm{H}_{2} \mathrm{O}+1 / 2 \mathrm{O}_{2}=>\mathrm{CaSO}_{4}+2 \mathrm{H}_{2} \mathrm{O}+\mathrm{dQ}
\end{gathered}
$$

Exhaust gases in the sprinkler containing burnt lime $(\mathrm{CaO})$ dust particles on the surfaces from which calcium sulphate $\left(\mathrm{CaSO}_{4}\right)$ was formed or calcium sulfite $\left(\mathrm{CaSO}_{3}\right)$, they are sprinkled with water in an amount ensuring its complete evaporation. The exhaust temperature before the electrostatic precipitator is reduced to safe values for the formation of condensation sulphuric acid $\left(\mathrm{H}_{2} \mathrm{SO}_{4}\right)$, above the dew point.

During the rapid contact of the sorbent with contaminated gas, there are chemical reactions involving the combination of sulfur oxides with an absorbing agent. As a result of the very high temperatures in the interior, the water evaporates at the same time, and the final product of the desulfurization process is dry [13]. The location of semi-dry desulfurization installation in the power station is presented in the figure below (Fig. 3).

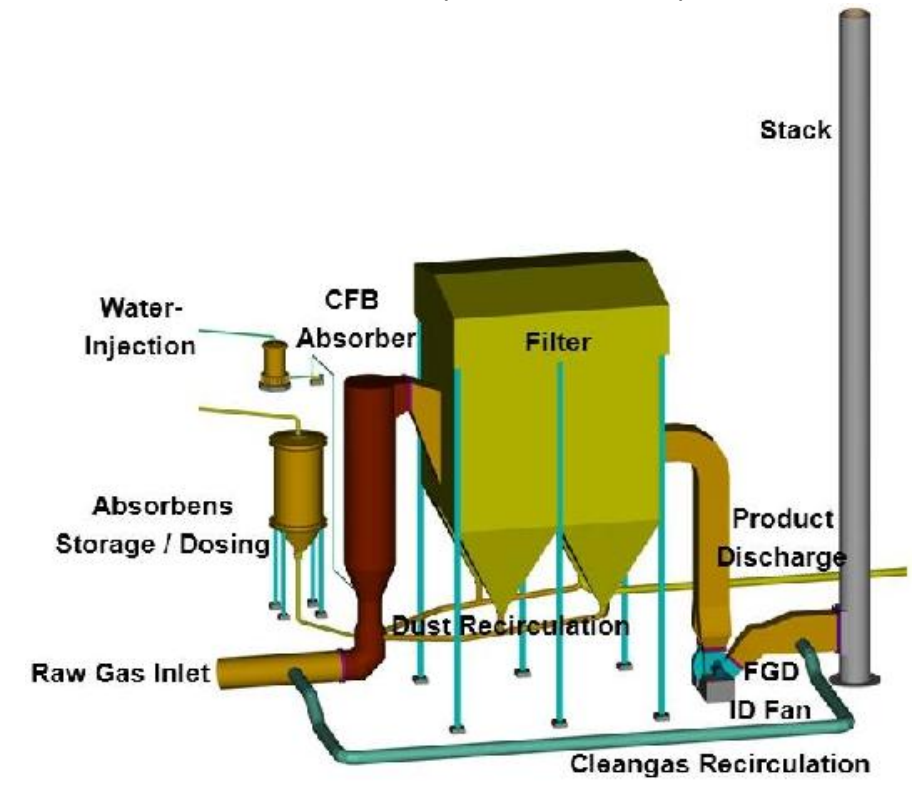

Fig. 3. Semi-dry desulfurization of exhaust gases Source: [15]

The method is characterized by the lower level of water usage during the removal of sulphides while obtaining the final product in a dry form. The final form of the extracted combustion dust in the semi-dry method is rarely used for other purposes. In addition, the usage of the sulphide absorbing agent exceeds the factor price used in the dry desulfurization technique.

\section{Flue gas denitrification method}

This method of selective non-catalytic reduction of nitrogen oxides is called SNCR (Selective Non-Catalytic Reduction) and is based on a high-temperature reaction gaseous ammonia or urea with nitrogen oxides without the catalyst. A ratio of 1 to 2.5 is assumed. The ratio determines the relation of the reactant to the nitrogen oxides depending on the degree of reduction and process assumptions [16].

The reduction process is conditioned not only by reaching the optimal temperature in the limit $850^{\circ} \mathrm{C}-1100^{\circ} \mathrm{C}$, but also proper distribution of the reagent in the exhaust. Too large particles evaporate too slowly, which translates into an increase in the unreacted amount of reagent, but too small particles evaporate too quickly, reacting in this way at the temperatures exceeding the optimum thus lessening the degree of reduction $\mathrm{NO}_{\mathrm{x}}$. The reactions occurring at too high temperatures can cause undesirable production of $\mathrm{NO}_{\mathrm{x}}$ through ammonia oxidation. The process at too low a temperature leads to the additional formation of ammonia. Achieving the appropriate and optimal conditions is essential, and is the most important issue in ensuring the efficiency of the SNCR method. 


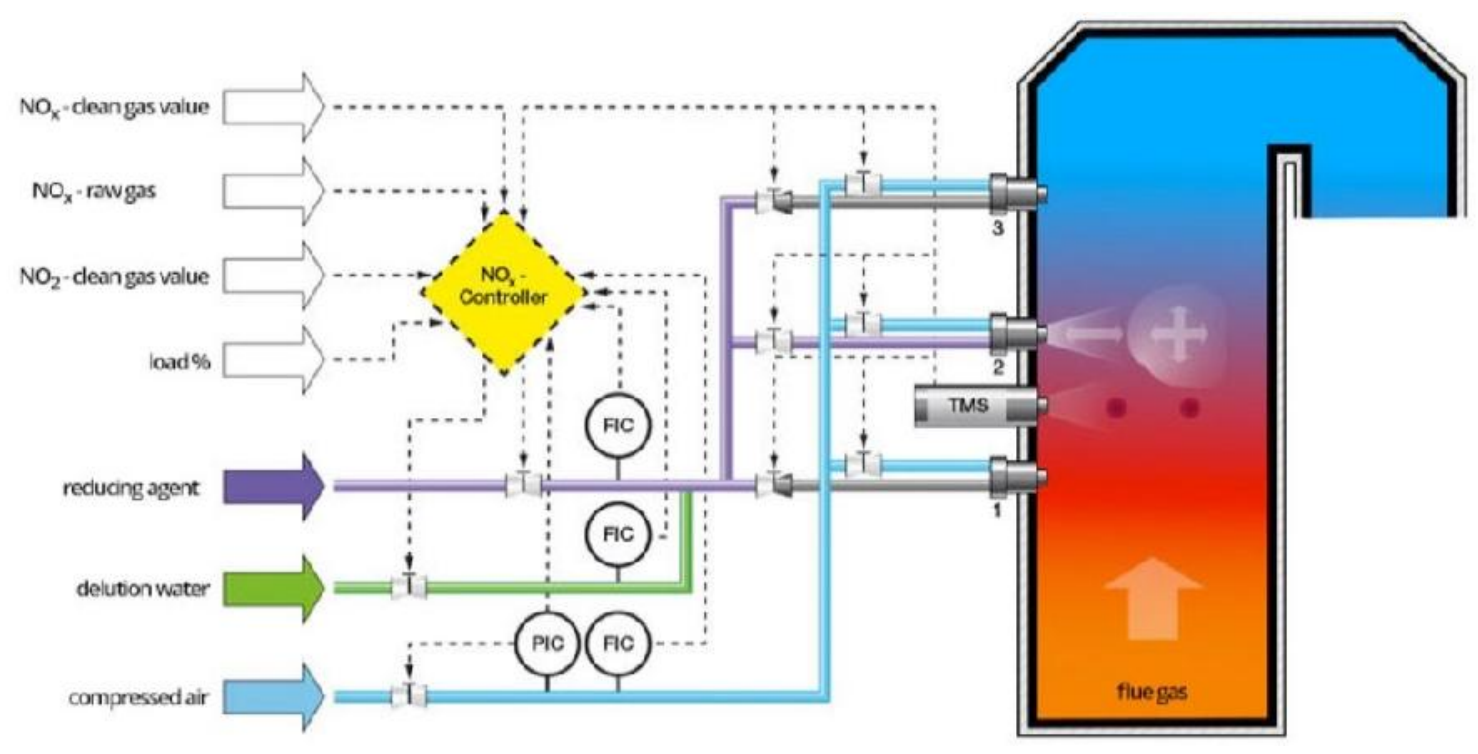

Fig. 4. Scheme of exhaust gas denitrification by the SNCR method Source: [17]

The SNCR installation type of "High Dust" is designed to work in a dusty and sulphated environment on the exhaust route directly behind the boiler and in front of the electrostatic precipitator. For this reason, it interferes with the existing systems of exhaust channels to a large extent, on operating parameters, and investment requirements for pressure systems of water heaters or steam.

\section{Exhaust gas dedusting}

Besides installation of the fuel combustion process in power units, there are dust removal devices from the exhaust. The first studies and patents related to electrostatic precipitators date back to the beginning of the 20th century. Effective equipment development has existed since the 1970s, under the influence of stricter standards in air cleanliness. New construction solutions appeared and the theory of electrostatic dedusting was better understood [18]. Work in the following decades was associated not only with obtaining a high level of effectiveness of action, but also with a high reliability and availability of these devices.

The electrofilters use the influence of the electrostatic field for solid particles (grains of dust) and liquid (mist drops), which is called an aerosol. The active space of the electrostatic precipitator (ESP) creates a high-voltage electrode system (corona discharge electrodes) and collection electrodes, placed relative to each other at certain intervals [19].

A very high constant voltage with negative polarity (up to $110 \mathrm{kV}$ ) is applied to the corona discharge electrodes. The corona electrodes are separated from the grounded electrofilter chamber and the electrodes collected use a special supporting structure mounted on suspension insulators. Collective electrodes, in turn, are mounted directly onto the elements of the electrostatic precipitator's chamber, thanks to which they have the potential for grounding. Thanks to the high voltage connection, a strong electric field is created between corona discharge electrodes and collection electrodes. Dust particles found in the gas stream flowing through the active space between electrodes are charged by negative ions and obtain a negative potential [20].

The charged solid particles are attracted by the surface of the collecting electrodes, with grounding potential, where they are under the influence of electric field forces. 


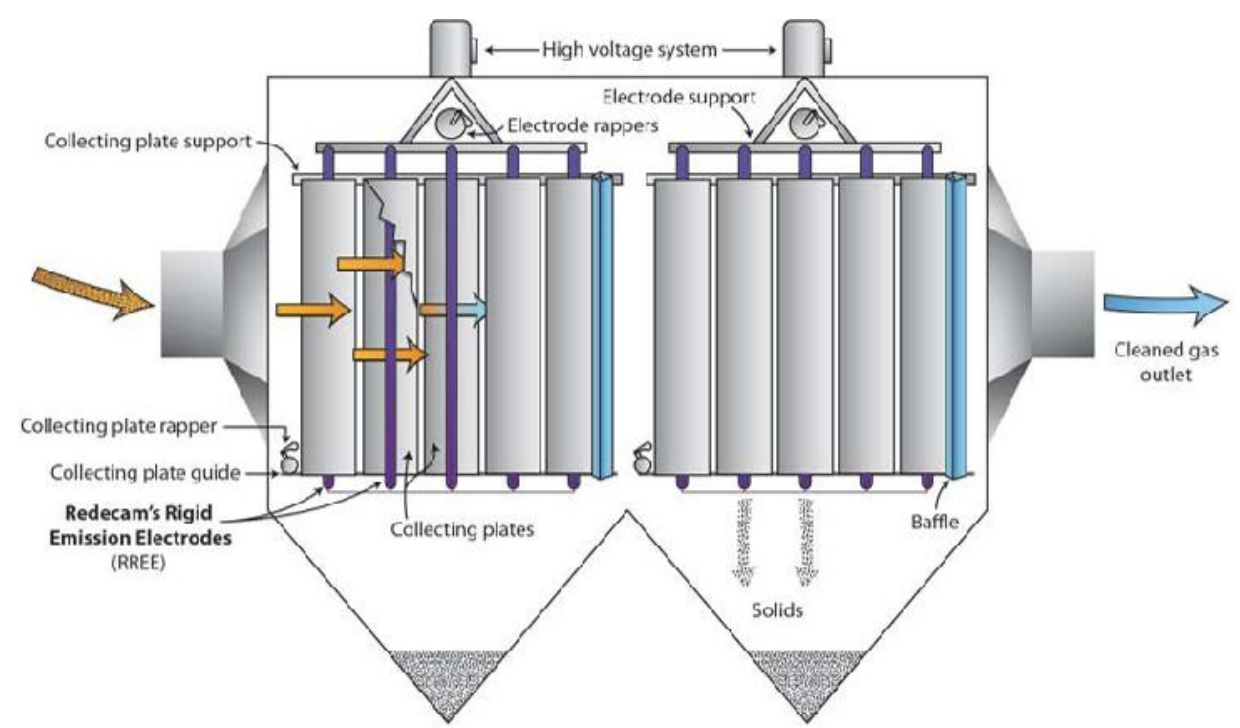

Fig. 5. Principle of ESP operation Source: [21]

The solid particles (dust, droplets of mist) settling on collecting electrodes are removed from them by the cyclic introduction of collecting electrodes into vibrations (dust flushing with collectors rapping devices, providing a sheer force greater than the force of electrostatic attraction). Collective electrodes are shaped in this way to collect the falling ash which was not captured again by the gas stream. Thanks to the appropriate shape of the electrodes and a special membrane located in the dust collecting hoppers, secondary dust entrainment is minimized and the efficiency of electrostatic precipitator removal is improved [22].

A small amount of dust also accumulates on the surface of the corona electrodes, therefore the corona electrodes are also cleaned, according to the same principle as collecting electrodes. As a result of the vibrations, the solid particles accumulated on the electrodes come under the influence of gravity to the dust collecting hoppers located at the bottom of the electrostatic precipitator. From the hoppers the is dust is collected continuously via an independent dust collection system.

\section{The future of power units}

No machine likes sudden load changes, it will only tolerate it or not. The carbon blocks have the right number of starts (and exceeding the permissible parameters, that happen in such states) and sooner or later material problems occur. Cracks will appear followed by failures of greater or lesser intensity.

In a publication available from the International Energy Agency (IEA), important recommendations concerning the modernization of the Polish energy sector are included. The document shows that many coal-fired power plants need to be replaced, which is a result of the long term use of the currently operating facilities [23]. Also in the IEA report, there are recommendations for Poland to take all actions into account for the impact on the protection of the environment and the impact of climate changes. To this end, the Polish government should develop a long-term strategy on climate policy for the coming years.

Furthermore, climate policy should include specific tasks aimed at reducing the emission of harmful chemical compounds, the problem that affects mainly the impact of $\mathrm{CO}_{2}$ on the natural environment (the greenhouse effect) and meeting strict standards which concern the emission of pollutants by large industrial facilities and executes the combustion process in a given region or province.

In addition to tips and recommendations for improving the energy sector, the IEA report also noted Poland's efforts. Energy security and energy efficiency were improved. The energy sector is facing serious demands which include: the implementation of the energy policy assumptions for the years beyond 2025 and the development of technological solutions maintaining the development prospects. Several companies are launching an initiative to transform the Polish power industry. 
The idea of "Duoblock" was developed by the Institute of Power Engineering, Silesian University of Technology in Gliwice, Energoprojekt - Katowice, TAURON and RAFAKO S.A in Katowice. The solution implemented by the above-mentioned companies perfectly fits in with the requirements contained in the BAT (Best Available Techniques) reference document and in the IEA (the International Energy Agency) report. The concept accurately takes into account the assumptions regarding the modernisation of current energy facilities. The main goal is to increase the fitness index and reduce the total emission of pollutants from the fuel combustion process, i.e. sulfur oxides, nitrogen oxides, dust and $\mathrm{CO}_{2}$ [24-25].

The "Duoblocks" project will start the changes, which must be introduced in the Polish power industry, in order to keep up with the changing standards related to environmental protection. In addition, the concept will provide the opportunity to introduce new installations to protect the environment from the emission of harmful chemical compounds, which is a by-product of the combustion of conventional fuels. The idea is generally to replace the currently working two power units with $200 \mathrm{MW}$ power - a new supercritical system.

The new solution will consist of two boilers, which will feed one class turbine 500 [25]. In addition, the project will ensure that power boilers can be fired with different fuels. The concept of "Duoblocks" will make it possible to extend the possibilities of conventional energy and will show the new potential of fossilized raw materials. In addition, the solution will improve the efficiency and the flexibility of the operation of objects from the area of the so-called traditional energy, including a coal-fired plant or biomass. Thus. It will give traditional solutions to compete with the growing RES (Renewable Energy Sources) area. Renewable energy sources have many advantages. However, the key drawback is the unpredictability of objects. The operation of RES installations mainly depends on the atmospheric conditions. Therefore, traditional solutions should also be modernised to guarantee constant access to electricity.

"Duoblocks" these are two boilers working on one turbine. The increasing importance of ecology and the requirements related to the flexibility of new blocks cause that "Duoblocks" are a solution willingly used in various parts of the world. The list of selected units is presented in the table below (Table 2.).

Table 2. Selected power plants equipped with energy "Duoblocks"

\begin{tabular}{|l|l|l|}
\hline \multirow{2}{*}{ The name of the source } & Installed power [MW] \\
\cline { 2 - 3 } & Boiler & Turbine \\
\hline Barbers Point (USA) & $2 \times 90$ & 180 \\
\hline Cedar Bay (USA) & $3 \times 90$ & 250 \\
\hline Eesti (Estonia) & $2 \times 108$ & 216 \\
\hline Balti (Estonia) & $2 \times 108$ & 216 \\
\hline Campha (Wietnam) & $4 \times 150$ & $2 \times 300$ \\
\hline CLECO (USA) & $2 \times 330$ & 660 \\
\hline Sandow (USA) & $2 \times 300$ & 600 \\
\hline Dominion (USA) & $2 \times 334$ & 660 \\
\hline Samcheok (Korea Płd.) & $4 \times 550$ & $2 \times 1100$ \\
\hline
\end{tabular}

Source: [26]

The solution with two boilers operating on one turbine has greater regulatory possibilities than monoblocks. Assuming that each single boiler has a technical minimum of $40 \%$ its rated power, a total minimum "Duoblocks" is obtained at $20 \%$ of the rated power. This allows you to work with the use of primary fuel, with a load of $18 \div 20 \%$ of the rated power of the duoblock, while maintaining the ability to rapidly increase power [26]. This is important especially in situations related to large fluctuations of energy demand and when it is necessary to quickly respond to a change in the system strain related to the work of unstable renewable energy sources.

The Polish power industry is currently mainly based on the combustion of hard coal and lignite. In the near future, the Polish energy policy will await the cyclical introduction of changes directed towards increasing the use of other fuels in the production of electricity. Gas, renewable sources or nuclear power will gradually replace coal. However, with a large share of renewable energy, which is characterized by instability, it should keep a very large amount of power in conventional power plants in reserve. 
The idea of "Duoblocks" will give the opportunity to implement improvements and modernise the existing energy infrastructure, which is now largely obsolete. Activities carried out in the conventional energy area will have to address compliance with strict standards and the assumptions created by the European Union. Requirements for monitoring the level of pollutant emissions in the industrial sector are set out in the BAT (Best Available Techniques) document. In addition, current installations found in traditional energy will have to meet certain conditions regarding the optimisation of technical parameters, which will eventually lead to the increased efficiency of power installations.

\section{Summary and conclusions}

The development of Polish energy mainly depends on the assumptions introduced by the European Union, including updates of applicable standards, regulations and ordinances, concerning the reduction of emission of dust removal (PM 10 and PM 2.5) and gas pollutants into the natural environment. Activities relating to the modernizations of methods and installations in the field of environmental protection were initiated by the Polish energy sector in the last decade of the twentieth century.

Modernizations at the turn of the year were aimed at a regular introduction installations for nitrogen removal, desulfurisation and dust removal. Concepts created in the present are going further in the direction of the improvement of existing energy facilities. The activities carried out are aimed at implementing solutions which will enable the fulfillment of the imposed environmental laws and standards. In addition, the activities carried out will contribute to increasing the opportunities for traditional solutions to compete in the coming years with the constantly developing area of renewable energy sources.

The Polish energy mix is mainly based on the combustion of hard coal and lignite. "Duoblocks" can expand the possibilities of conventional energy. They allow to improve the efficiency and flexibility above all of conventional energy, including coal and biomass facilities. They are focused on traditional, conventional solutions but in such a way that they can compete with other energy sources, mainly such as renewable energy obtained from windmills or solar panels, which with all the advantages have one drawback, renewable energy sources are unpredictable because they depend on the whims of the weather.

\section{References}

[1] Pawlik M., Zaawansowane technologicznie bloki energetyczne - Nowe wyzwania, Energetyka, sierpień 2013, pp. 595-596.

[2] Action Plan for Energy Efficiency, Realising the Potential, Brussels, 19-10-2006 COM (2006) 545 final.

[3] Zaporowski B., Technologie wytwarzania energii elektrycznej dla polskiej elektroenergetyki, Polityka Energetyczna - Energy Policy Journal, v. 18, 2015, pp. 29-44.

[4] Green Paper, A European Strategy for Sustainable, Competitive and Secure Energy, Brussels, 8.3.2006, pp. 17-18.

[5] Directive 2010/75/EU of the European Parliament and of the Council of 24 November 2010 on industrial emissions (integrated pollution prevention and control) (Recast), pp. 1-2.

[6] Minister for the Environment in Poland, Regulation of the Minister for the Environment of 30th October 2014 on the requirements for the measurement of emission volumes and the amount of water abstracted, Official Gazette, 2014/1542, 2014, pp. 1-3.

[7] Minister for the Environment in Poland, Regulation of the Minister for the Environment of 4th November 2014 on the emission standards for certain types of installation, fuel combustion plants and waste incineration or co-incineration facilities, Official Gazette, 2014/1546, 2014, pp. 19-25.

[8] Brzezińska A., IT systems supporting the Polish energy sector in proecological activities, Publisher Energy Market (Rynek Energii), Nr 2 (135), 2018, pp. 39.

[9] Chmielniak T., Rusin A., Łukowicz H., Modernizacja i rewitalizacja istniejących bloków węglowych ważnym warunkiem stabilności sektora wytwarzania elektryczności, Polityka Energetyczna - Energy Policy Journal, v. 19, 2016, pp. 49-59.

[10] Szczepańska J., Emission of major pollutants, The air, vol. 3, www.wios.lodz.pl/files/docs/r11xiiixpo wietrze.pdf, available: 05.07.2018, pp. 106.

[11] Myśliński A., Metody odsiarczania gazów odlotowych, www.chem.uw.edu.pl/people/AMyslinski/JS/wyk_ 03.ppt, available: $25 \cdot 10.2018$. 
[12] Hamon, Wet flue gas desulfurization with lime/limestone slurry, https://www.hamon.com/solutions/acidgas-removal/wet-flue-gas-desulfurization-with-lime-limestone-slurry/, available: 08.10.2018.

[13] Wardak P., The investment process and NOx and SOx Reduction Methods on the example of selected Polish power facilities, Modern Power Industry in Central and Eastern Europe, 2015, pp. 4-5.

[14] Carmeusena, Dry scrubbing, http://www.carmeusena.com/markets/flue-gas-treatment/dry-scrubbing, available: 08.03.2019.

[15] Hamon, Semi-dry flue gas desulfurization, https://www.hamon.com/solutions/acid-gas-removal/desox-6/, available: 08.10.2018.

[16] Kordyaczny H., Śpiewak I., Modern flue gas denitrificaton technologies for the power industry and other industrial branches vs changing environmental regulations, Energetyka, 2016, pp. 723-727

[17] ERC Technik, SNCR plants, http://www.erc-online.de/en/erc-technik/plants/denox-plants/sncr/, available: 08.10.2018.

[18] Biedrzycka A., Elektrofiltry w energetyce. Do wymiany lub modernizacji, materiał pokonferencyjny "Elektrofiltry 2004”, http://www.gigawat.net.pl/archiwum/article/articleprint/407/-1/46/index.html, 2004, available: 18.09.2018.

[19] Shah K. P., Construction, Working, Operation and Maintenance of Electrostatic Precipitators (ESPs), 2017, pp. 5-11.

[20] Suleman M., Saleem M., Siebenhofer M., Characterization of brush type discharge electrodes and the impact of enhanced corona discharge on the operation of electrostatic precipitators, Journal of Electrostatics, v. 70, 2012, pp. 144-148.

[21] Redecam Group, Electrostatic Precipitators, http://www.redecam.com/electrostatic-precipitators/, available: 18.09.2018.

[22] Tracz P., Biały L., Wacławiak K., Directions of improvements of modern electrostatic precipitators, Archives of Waste Management and Environmental Protection, 18, 2016, pp. 2-6.

[23] IEA, Energy Policies of IEA Countries, Polish 2016 Review, Executive Summary Polish, https://www.iea.org/publications/freepublications/publication/EnergyPoliciesofIEACountriesPolish2016R eviewExecutiveSummaryPolish.pdf, available:03.10.2018.

[24] ENERGOPROJEKT - KATOWICE S.A., DUOBLOK 500 jako rozwiązanie dla rekonstrukcji bloków 200 MW, http://www.igeos.pl/images/files/2016/1717/MZmija.pdf, available 09.09.2018.

[25] Best Available Techniques (BAT) Reference Document for Large Combustion Plants Industrial Emissions Directive 2010/75/EU (Integrated Pollution Prevention and Control) Joint Research Centre, Institute for Prospective Technological Studies, Sustainable Production and Consumption Unit, European IPPC Bureau, Final Draft, 2016.

[26] Paska J., Pawlak K., Duobloki energetyczne jako potencjalny element strategii rewitalizacji sektora wytwarzania energii elektrycznej w Polsce, Rynek Energii, 2014, pp. 6-7. 